\title{
JNPH
}

Volume 7 No. 1 (April 2019)

(C) The Author(s) 2019

\section{HUBUNGAN PENGETAHUAN DENGAN KEJADIAN INFEKSI MENULAR SEKSUAL DI PUSKESMAS PENURUNAN KOTA BENGKULU TAHUN 2018}

\section{CORRELATION BETWEEN KNOWLEDGE WITH SEXUAL CONTAGIOUS INFECTION AT PENURUNAN PUBLIC HEALTH CENTER BENGKULU CITY IN 2018}

\author{
FIYA DINIARTI ${ }^{1}$, EPINA FELIZITA 2, HASANUDIN ${ }^{3}$ \\ DOSEN PROGRAM STUDI KESEHATAN MASYARAKAT \\ DI FAKULTAS ILMU KESEHATAN DEHASEN \\ JALAN MERAPI RAYA NO.43 KEBUN TEBENG KOTA BENGKULU \\ Email: Fiyadiniarti@yahoo.co.id
}

\begin{abstract}
ABSTRAK
Infeksi Menular Seksual (IMS) adalah infeksi yang ditularkan melalui hubungan seksual baik secara vaginal, anal dan oral. Berdasarkan data Kemenkes 2012 didapatkan kasus IMS sebanyak 140.803 kasus, data dari Dinas Kesehatan Kota Bengkulu jumlah kasus IMS pada WPS sebanyak 148 kasus, dan Data laporan tahunan di UPTD Puskesmas Penurunan Kota Bengkulu ditahun 2017 sebanyak 86 kasus. Tujuan penelitian Untuk mengetahui hubungan pengetahuan dengan kejadian infeksi menular seksual (IMS) di wilayah kerja Puskesmas Penurunan Kota Bengkulu Tahun 2018. Penelitian ini menggunakan metode kuantitatif secara analitik, analisa data Univariat dan Bivariat dengan jenis desain Cross Sectional.Jumlah sampel 88 responden dengan teknik pengambilan sampel secara Accidental Sampling dengan menggunakan instrument kuesioner, uji Chi-square, dan pengolahan data menggunakan SPSS 16.0. Hasil Penelitian ini didapatkan bahwa ada hubungan antara pengetahuan dengan kejadian Infeksi menular seksual (IMS). Berdasarkan hasil uji statistic Chi square $\mathrm{p}=0,00<\alpha(0,05)$. Berdasarkan hasil penelitian dapat disimpulkan bahwa hubungan antara pengetahuan dengan kejadian Infeksi menular seksual (IMS). Saran bagi Puskesmas agar dapat memberikan informasi kepada masyarakat terkait penanggulangan penyakit IMS melalui media offline dan online secara kontinue dan sustainable.
\end{abstract}

Kata Kunci: Infeksi menular seksual, pengetahuan

\begin{abstract}
Sexual Contagious infection (IMS) is an infection which spread during sexual activity from vaginal, oral and anal. According to data from Kemenkes in 2012, there are 140.803 IMS cases, data from Health Department of Bengkulu City shows that there are 148 cases of IMS and WPS, data from annual report of UPTD Public Health Center of Penurunan Bengkulu City shows that there are 86 cases in 2017. The purpose of this research is to find out the correlation between knowledge with sexual contagious infection (IMS) at Penurunan Public Health Center Bengkulu city in 2018. This research uses quantitative method with analytic, data are analyzed by using univariate and bivariate with cross-sectional design. There are 88 respondents as
\end{abstract}


sample, sample are taken by using Accidental Sampling with Instrumental Questionnaire, Chisquare test and data are processed by using SPSS 16.0. The research result shows that there is a correlation between knowledge with Sexual contagious infection (IMS). According to chisquare statistics test, $\mathrm{p}=0,00<\alpha(0,05)$. According to research result, it can be concluded that there is a correlation between knowledge with Sexual Contagious Infection (IMS). It is expected that Public Health Center can inform society about IMS prevention thru offline and online media continually and sustainable.

\section{Keywords: Sexual Contagious Infection, Knowledge}

\section{PENDAHULUAN}

Infeksi menular seksual merupakan penyakit menular seksual yang menjadi masalah kesehatan di Indonesia dan di Dunia.Infeksi menular seksual menjadi pandemic dan mengancam penduduk dunia dengan berbagai dampak sosial dan ekonomi yang ditimbulkan.

Menurut World Health Organization (WHO) lebih dari 1 juta orang mendapatkan Penyakit Menular Seksual (PMS) setiap hari. Setiap tahun sekitar 500 juta orang menjadi sakit dengan salah satu dari 4 (empat) Penyakit Menular Seksual (PMS) yaitu Klamidia, Gonore, Sifilis dan Trikomoniasis. WHO dan UNAIDS memperkirakan bahwa lebih dari 35,3 juta orang terinfeksi HIV di seluruh dunia, dan $90 \%$ dari mereka berada di Negara berkembang (UNAIDS, 2013). Mayoritas Penyakit Menular Seksual (PMS) hadir tanpa gejala.Beberapa Penyakit Menular Seksual (PMS) dapat meningkatkan risiko penularan Human Immunodeficiency Virus (HIV) tiga kali lipat atau lebih (WHO, 2013).

Data profil pengendalian penyakit dan penyehatan lingkungan tahun 2012 didapatkan total kasus Infeksi Menular Seksual (IMS) yang ditangani pada tahun 2012 sebanyak 140.803 kasus dari 430 layanan Infeksi Menular Seksual (IMS). Jumlah kasus terbanyak berupa cairan vagina abnormal (klinis) 20.962 dan servicitis (lab) 33.025 Infeksi Menular Seksual (IMS) merupakan salah satu pintu masuk atau tandatanda adanya HIV (Kemenkes, 2013).

Penderita Infeksi Menular Seksual (IMS) sebagian besar berada di Asia Selatan dan Asia Tenggara yaitu sebanyak 151 juta, diikuti Afrika sekitar 70 juta, dan yang terendah adalah Australia dan Selandia Baru sebanyak 1 juta. Semakin lama jumlah penderita Infeksi Menular Seksual (IMS) semakin meningkat dan penyebarannya semakin merata di seluruh dunia.WHO memperkirakan morbiditas Infeksi Menular Seksual (IMS) di dunia sebesar \pm 250 juta orang setiap tahunnya.Peningkatan insidensi Infeksi Menular Seksual (IMS) ini terkait juga dengan perilaku berisiko tinggi yang ada di masyarakat dewasa ini (Widoyono, 2011).

Infeksi Menular Seksual (IMS) di Negara-negara berkembang dan komplikasinya menduduki peringkat ke-lima teratas kategori penyakit dewasa yang banyak memerlukan perawatan kesehatan.Infeksi Menular Seksual (IMS) dapat menyebabkan gejala akut, infeksi kronis dan konsekuensi serius seperti infertilitas, kehamilan ektopik, kanker leher rahim dan kematian mendadak pada bayi dan orang dewasa (Saroso, 2012).

Angka kejadian Infeksi Menular Seksual (IMS) saat ini cenderung meningkat di Indonesia misalnya prevalensi sifilis meningkat sampai $10 \%$ pada beberapa kelompok Wanita Pekerja Seks (WPS), 35\% pada kelompok waria dan 2\% pada kelompok ibu hamil, prevalensi gonore meningkat sampai $30-40 \%$ pada kelompok Wanita Pekerja Seksual (WPS). Penyebaran Infeksi Menular Seksual (IMS) sulit ditelusuri sumbernya, sebab tidak pernah dilakukan registrasi terhadap penderita yang ditemukan.Jumlah penderita yang sempat terdata hanya sebagian kecil dari jumlah penderita sesungguhnya (Daili, SF, 2010).

Data dari Provinsi Bengkulu pada tahun 2015 ditemukan kasus HIV sebanyak 64 
kasus yaitu laki-laki 30 orang dan perempuan 34 orang, kasus AIDS sebanyak 41 kasus yaitu laki-laki 27 orang dan perempuan 14 orang, kasus Infeksi Menular Seksual (IMS) terdapat 13 kasus yaitu laki-laki 5 orang dan perempuan 8 orang. Pada tahun 2016 kasus HIV didapati 181 kasus yaitu laki-laki 104 dan perempuan 77 orang, lalu kasus AIDS didapati sebanyak 31 kasus yaitu laki-laki 20 orang dan perempuan 11 orang, dan kasus Infeksi Menular Seksual (IMS) didapati 11 kasus dengan jenis kelamin laki-laki semua (Dinkes Prov.Bengkulu, 2016).

Data Dinas Kesehatan Kota Bengkulu pada tahun 2017 menunjukkan ada 1.317 jumlah kasus kunjungan pasien IMS.Pada Wanita Pekerja Seksual (WPS) didapatkan 542 jiwa.Di Kota Bengkulu jumlah kasus IMS pada Wanita Pekerja Seksual (WPS) yang ditemukan sebanyak 148 kasus dan jumlah kasus IMS yang telah diobati sebanyak 143 kasus. Adapun jenis-jenis IMS yang ditemukan pada Wanita Pekerja Seksual (WPS) yaitu Sifilis Dini 2 kasus, Gonore 5 kasus, Servitis/Proctitis 103 kasus, dan Trikomoniasis didapatkan 2 kasus (Dinas Kesehatan Kota Bengkulu, 2017).

Data laporan tahunan di UPTD Puskesmas Penurunan Kota Bengkulu menunjukkan bahwa pada tahun 2015 terdapat 1.179 kunjungan layanan Infeksi Menular Seksual (IMS), ditahun 2016 terdapat 841 kunjungan layanan Infeksi Menular Seksual (IMS), dan ditahun 2017 didapati 692 kunjungan layanan Infeksi Menular Seksual (IMS) yaitu terdapat 282 Wanita Pekerja Seksual (WPS) dengan jumlah kasus Infeksi Menular Seksual (IMS) yang ditemukan sebesar 86 kasus (Puskesmas penurunan, 2017).

Berdasarkan penelitian bahwa status pernikahan banyak yang tidak menikah dan cerai, dibandingkan yang masih terikat pernikahan yang sah.Wanita Pekerja Seksual (WPS) yang tidak menikah dan cerai bebas bekerja sebagai Wanita Pekerja Seksual (WPS) tanpa ikatan atau batasan dari suami. Sejalan dengan penelitian Aprilianingrum (2006) yang menunjukkan bahwa status yang tidak menikah berisiko 2.63 kali untuk terkena Infeksi, Menular Seksual (IMS) dibandingkan yang menikah. Didukung oleh penelitian Boyer at all (2008) yang menunjukkan bahwa status cerai dan tidak menikah berhubungan dengan risiko seksual OR 3.24, IK 95\% (Febrianingsih, 2014).

Berdasarkan survey awal yang dilakukan peneliti di wilayah kerja UPTD Puskesmas Penurunan Kota Bengkulu dari 10 responden yang berkunjung ke Puskesmas Penurunan ditemukan 8 responden tidak mengetahui tentang penyebab, gejala dan dampak dari infeksi menular seksual dinyatakan positif terkena Infeksi Menular Seksual (IMS).

Berdasarkan latar belakang diatas maka peneliti tertarik untuk melakukan penelitian tentang "Hubungan pengetahuan dengan kejadian infeksi menular seksual (IMS) di Wilayah Kerja Puskesmas Penurunan Kota Bengkulu tahun 2018.

\section{METODE PENELITIAN}

Penelitian ini menggunakan metode penelitian Analitik deskriptif dengan rancangan cross Sectional. Penelitian Cross sectional adalah suatu penelitian dimana pengumpulan data variable independen dan variable dependen dilakukan pada saat bersamaan (Saryono, 2011).Populasi dalam penelitian ini adalah seluruh responden (wanita usia reprodukstif) yang berkunjung ke Puskesmas Penurunan. Tekhnik yang dipakai untuk mengambil sampel pada penelitian ini adalah tekhnik sampel Accidental Sampling. Jumlah sampel pada penelitian ini 88 orang. Teknik pengumpulan data yang digunanakan dalam penelitian ini adalah dengan menggunakan data primer dan data sekunder.analisis data dengan menggunakan analisis univariat dan bivariate (dengan uji chi-square). Pengolahan data dengan mengunakan computer dilakukan melalui beberapa tahap antara lain: Editing, Coding, Tabulating, Entry data, Cleaning dan Saving. 


\section{HASIL PENELITIAN}

\section{Analisa Univariat}

Penganalisaan variabel tunggal (Univariat) ini untuk melihat distribusi frekuensi masing-masing variabel. Responden dalam penelitian ini semua WPS yang berkunjung ke Puskesmas Penurunan Kota Bengkulu dan jumlah sampel yang diteliti sebanyak 74 responden.

Tabel 1 Distribusi Frekuensi Berdasarkan Pengetahuanpada Kelompok Beresiko di Wilayah Kerja UPTD Puskesmas Penurunan Kota Bengkulu Tahun 2019

\begin{tabular}{cccc}
\hline No & Pengetahuan & Frekuensi & Persentase \\
\hline 1. & Kurang & 32 & $36,4 \%$ \\
\hline 2. & Baik & 56 & $63,6 \%$ \\
\hline & Jumlah & $\mathbf{7 4}$ & $\mathbf{1 0 0 \%}$ \\
\hline
\end{tabular}

Berdasarkan tabel 1 menunjukkan bahwa sebagian kecil mempunyai pengetahuan kurang.

Tabel 2 Distribusi Frekuensi Berdasarkan Kejadian Infeksi Menular Seksual (IMS) pada kelompok Beresiko di Wilayah Kerja UPTD Puskesmas Penurunan Kota Bengkulu Tahun 2019

\begin{tabular}{lccc}
\hline No & Kejadian IMS & Frekuensi & Persentase \\
\hline 1. & IMS & 51 & $58,0 \%$ \\
\hline 2. & Tidak IMS & 37 & $42,0 \%$ \\
\hline & Jumlah & $\mathbf{7 4}$ & $\mathbf{1 0 0 \%}$ \\
\hline
\end{tabular}

Berdasarkan tabel 2 menunjukkan bahwasebagianbesar positif IMS.

\section{Analisa Bivariat}

Analisis bivariat dilakukan dengan uji chi-square yang digunakan untuk menguji hipotesis hubungan yang signifikan antara prmgetahuan dengan kejadian IMS di Wilayah Kerja Puskesmas Penurunan Kota Bnegkulu. Dasar pengambilan keputusan adanya hubungan tersebut berdasarkan tingkat kesalahan $(\alpha)=0,05$, dengan penafsiran signifikansi (nilai p) yaitu :

a. Jika nilai $\mathrm{p} \leq 0,05$ maka ada hubungan

b. Jika nilai $\mathrm{p}>0,05$ maka tidak ada hubungan

Tabel 3 Hubungan antara Pengetahuan dengan Kejadian Infeksi Menular Seksual (IMS) Pada Kelompok Berisiko di Wilayah Kerja UPTD Puskesmas Penurunan Kota Bengkulu Tahun 2019.

\begin{tabular}{|c|c|c|c|c|c|c|}
\hline \multirow{3}{*}{$\begin{array}{l}\text { Pengeta- } \\
\text { huan }\end{array}$} & \multicolumn{4}{|c|}{ Kejadian IMS } & Total & \multirow{3}{*}{$\begin{array}{l}\text { P. OR } \\
\text { Va- }(95 \% \\
\text { lue :CI })\end{array}$} \\
\hline & \multicolumn{2}{|c|}{ IMS } & \multicolumn{2}{|c|}{ Tidak IMS } & \multirow{2}{*}{$\%$} & \\
\hline & $\mathrm{F}$ & $\%$ & $\mathrm{~F}$ & $\%$ & & \\
\hline Kurang & 27 & 30,7 & 5 & 5,7 & $32 \quad 36,4$ & \\
\hline Baik & 24 & 24,3 & 32 & 36,4 & $56 \quad 63,6$ & 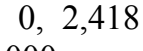 \\
\hline 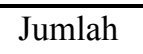 & 51 & 8,0 & 37 & 42,0 & $88 \quad 100$ & \\
\hline
\end{tabular}

Berdasarkan tabel 3 hasil uji statistik Chi-square(continuity correction) didapat nilai $\mathrm{p}($ value $)=0,000<0,05$, maka Ho ditolak dan Ha diterima. Berati terdapat hubungan pengetahuan dengan kejadian infeksi menular seksual (IMS). Dari nilai Ods Ratio (OR) sebesar 2,418 (OR $>1)$ dapat disimpulkan bahwa pengetahuan yang rendah lebih beresiko 2,418 kali untuk menderita kejadian IMS menderita kejadian IMS.

\section{PEMBAHASAN}

\section{Analisis Univariat}

\section{a. Distribusi Frekuensi Berdasarkan Pengetahuan pada Kelompok Beresiko di Wilayah Kerja UPTD Puskesmas Penurunan Kota Bengkulu Tahun 2019}

Berdasarkan tabel 1 disimpulkan bahwa sebagian besar pengetahuan kurang. Alasan responden pengetahuan kurang.dikarenakan akses informasi yang didapatkan kurang. Akses informasi online maupun ofline belum dilakukan secara kontinue dan sustainable. Pengetahuan mempunyai peran yang sangat penting mempengaruhi perilaku seseorang 
dalam upaya promotif dan preventif penanggulangan infeksi menular seksual.

\section{b. Distribusi Frekuensi Kejadian Infeksi menular seksual (IMS) di Wilayah Kerja UPTD Puskesmas Penurunan Kota Bengkulu Tahun 2019}

Berdasarkan tabel 2 disimpulkan bahwa sebagian besar responden IMS yang positif.Adapun jenis IMS yang ditemukan pada responden yaitu Gonorhae, sifilis, herpes genital dan klamidia.

\section{Analisis Bivariat}

\section{c. Hubungan antara Pengetahuan dengan kejadian Infeksi Menular Seksual (IMS) di Wilayah Kerja UPTD Puskesmas Penurunan Kota Bengkulu Tahun 2019}

Berdasarkan tabel 3 hasil uji statistik Chi-square didapat nilai $\mathrm{p}($ value $)=0,000<$ 0,05 berarti Ho ditolak dan Ha diterima yang artinya terdapat hubungan antara Pengetahuan dengan kejadian IMS.

Menurut (Skinner, B.F 2013). Pengetahuan merupakan hasil dari tahu dan ini terjadi setelah orang melakukan penginderaan terhadap suatu objek tertentu. Penginderaan terjadi melalui panca indera manusia. Sebagian pengetahuan manusia diperoleh melalui mata dan telinga. Pengetahuan yang dimaksud dalam penelitian ini adalah kemampuan responden untuk dapat menjawab pertanyaan tentang infeksi menular seksual (IMS).

Menurut Penelitian (Olfi dkk, 2015) terdapat hubungan antara pengetahuan dengan tindakan pencegahan penyakit menular seksual pada siswa di SMA Dharma Wanita Pineleng. Hasil chi square didapatkan hasil $p=0,000>=0,05$.

\section{KESIMPULAN}

Berdasarkan hasil penelitian tentang Pengetahuan dengan kejadian infeksi menular seksual (IMS) di Wilayah Kerja UPTD
Puskesmas Penurunan Kota Bengkulu Tahun 2018 maka dapat ditarik kesimpulan sebagai berikut :

1. Sebagian besar responden mempunyai pengetahuan kurang di Wilayah Kerja UPTD Puskesmas Penurunan Kota Bengkulu.

2. Sebagian besar responden positif IMS di UPTD Puskesmas Penurunan Kota Bengkulu.

3. Ada hubungan antara pengetahuan dengan Kejadian IMS di UPTD Puskesmas Penurunan Kota Bengkulu.

\section{SARAN}

Berdasarkan hasil penelitian yang telah dilakukan, maka peneliti menyarankan pada beberapa pihak terkai sebagai berikut :

1. Bagi peneliti

Sebagai acuan untuk diadakan penelitian lebih lanjut tentang faktor risiko Kejadian IMS terkait variabel metode IT terkait pencegahan IMS, Metode Kontrasepsi.

2. Bagi Puskesmas Penurunan Kota Bengkulu

Hasil penelitian ini dapat dijadikan sumber informasi bagi pihak Puskesmas Penurunan dalam melakukan penyuluhan dalam meningkatkan pelayanan, dan dapat mencegah penyakit Insfeksi Menular Seksual (IMS).

\section{DAFTAR PUSTAKA}

Ali. 2012. Faktor yang berhubungan dengan Kejadian IMS pada WPS. Universitas Muhammadiyah Surakarta. Surakarta

Arikunto, S. 2006. Prosedur Penelitian Suatu Pengantar Praktik. Jakarta: Rineka Cipta

Budiman \& Riyanto A. 2013. Kapita Selekta Kuesioner Pengetahuan dan Sikap Dalam Penelitian Kesehatan.Jakarta : Salemba Medika pp 66-69

Daili, SF., 2010. Infeksi Menular Seksual 
dalam ilmu Penyakit Kulit dan Kelamin, Edisi ke-6, Penerbit FKUI. Jakarta

Darmayansyah. 2013. Skripsi. Hubungan Antara Umur, Pendidikan, Dan Pekerjaan Dengan Risiko Terjadinya IMS Di Bali. Fakultas Kedokteran Universitas Udayana/Rsup Sanglah Denpasar

Dewi. 2010. Stusi Kualitatif Pengetahuan Ibu Rumah Tangga Terhadap Kejadian IMS di Kota Depok, Fakultas Kesehatan Masyarakat Universitas Indonesia

Dinas Kesehatan Provinsi Bengkulu, 2015. Profil Kesehatan Provinsi Bengkulu. Dinas Kesehatan Provinsi Bengkulu

Dinas Kesehatan Provinsi Bengkulu, 2016. Profil Kesehatan Provinsi Bengkulu. Dinas Kesehatan Provinsi Bengkulu

Dinas Kesehatan Kota Bengkulu, 2016.Profil Kesehatan Kota Bengkulu. Dinas Kesehatan Kota Bengkulu

Dinas Kesehatan Kota Bengkulu, 2017.Data Bulanan Penyakit IMS Dinas Kesehatan Kota Bengkulu. Dinas Kesehatan Kota Bengkulu

Edy W, 2009.Praktik Wanita Pekerja Seks (WPS) Dalam Mencegah Penyakit Infeksi Menular Seksual (IMS) Dan HIV\&AIDS Di Lokalisasi Koplak, Kabupaten Grobogan. Jurnal Promosi Kesehatan Indonesia

Febrianingsih, 2014.Faktor-faktor yang berhubungan dengan kejadian Infeksi Menular Seksual pada Pasien yang Datang Berobat di Klinik Infeksi Menular Seksual Puskesmas Limba B Kecamatan Kota Selatan. Gorontalo Tahun 2014

Fitriana, 2012.Penggunaan Kondom dan Vaginal Hygiene sebagai Faktor Risiko Kejadian IMS pada WPS di Lokalisasi Batu 24 Kabupaten Bintan.Jurnal Kesehatan Masyarakat, Vol.I, Nomor 2, th.2012, hlm.357-363

Gilly A, 2010.Buku Ajar Kesehatan Reproduksi Wanita, EGC. Jakarta

Budiono, 2011.Konsistensi Penggunaan Kondom Oleh Wanita Pekerja Seksual/Pelanggannya.Jurnal Kesehatan
Masyarakat

Kemenkes RI, 2017. Jenderal Pencegahan dan Pengendalian Penyakit Petunjuk Teknis Monitoring Klinis dan Program HIV AIDS dan PMS. Jakarta

Kemenkes RI, 2009. B-13 Mitos dan fakta: Modul Pelatihan Intervensi Perubahan Perilaku Paket Satu. Jakarta

Kurniawati. 2013. Naskah Publikasi. Pengaruh Pendidikan IMS Menggunakan Diskusi Kelompok Kecil Dengan Fasilitator Terhadap Tingakt Pendidikan Dan Pengetahuan WPS Di Rusun Begalon Surakarta. Universitas Muhamadiyah Surakarta

Notoatmodjo.2010. Metodologi Penelitian Kesehatan. Rineka Cipta: Jakarta

Notoatmodjo, 2012.Pendidikan dan Perilaku Kesehatan. Jakarta: Rineka Cipta

Pusat Informasi Penyakit Infeksi dan Penyakit Menular, 2010.Infeksi Menular Seksual di Indonesia, Situs Resmi Rumah Sakit Penyakit Infeksi Prof. Dr.Sulianti Saroso (Serial online), http://www.infeksi.com/data/newsin.xml. (5 Desember 2012)

Purwatiningsih, W. 2014.Asuhan Keperawatan Maternitas. Yogyakarta: ISBN

Puskesmas Penurunan Kota Bengkulu, 2016.Profil Puskesmas Penurunan

Puskesmas Penurunan Kota Bengkulu, 2015.Laporan Bulanan Puskesmas Penurunan

Puskesmas Penurunan Kota Bengkulu, 2016.Laporan Bulanan Puskesmas Penurunan

Puskesmas Penurunan Kota Bengkulu, 2017.Laporan Bulanan Puskesmas Penurunan

Setyawulan, 2007.Hubungan praktek Pencegahan Penyakit Menular Seksual dengan Kejadian Penyakit Menular

WHO, 2013.Factsheet of Sexually Transmitted Infections (STI's) http://www.who.int/reproductivehealth/p ublications/rtis/rhr13 02/en/

Widoyono, 2011.Penyakit Tropis Epidemiologi, Penularan, Pencegahan 
\& Pemberantasan. Jakarta: Erlangga

Mamarodia Olfi, Kandou D Grace dan Suling L Pieter (2017). Thesis: Hubungan anatara penegtahuan, sikap, peran orang tua dan ketaatan beragama dengan tindakan pencegahan penyakit menular seksual pada siswa di SMA Dharma wanita Pinelang. FKM. Universitas Sam Ratulangi: Manado 